\title{
The Harmony in Mesoamerican Mathematics
}

\author{
Everardo Lara', Natalia Sgreccia ${ }^{2}$ \\ ${ }^{1}$ Assembly for Culture and Democracy C.A., Distrito Federal, México \\ ${ }^{2}$ National University of Rosario, Rosario, Argentina \\ Email: cenzontli400@hotmail.com,nataliasgreccia@hotmail.com
}

How to cite this paper: Lara, E. and Sgreccia, N. (2018) The Harmony in Mesoamerican Mathematics. Open Access Library Journal, 5: e4306.

https://doi.org/10.4236/oalib.1104306

Received: January 3, 2018

Accepted: February 21, 2018

Published: February 24, 2018

Copyright $\odot 2018$ by authors and Open Access Library Inc.

This work is licensed under the Creative Commons Attribution International License (CC BY 4.0).

http://creativecommons.org/licenses/by/4.0/

\begin{abstract}
We present some metaphorical meanings of Anáhuac people specially regarding to numbers and basic operations, which underline the importance of the nature, the family, the culture, the human harmony. This indigenous knowledge could complement classes of Mathematics and makes sense more powerful. Our experiences with students and teachers of Latin America show us that it is possible and empowers people.
\end{abstract}

\section{Subject Areas}

Education

\section{Keywords}

Anáhuac, Nepohualtzitzin, Numbers, Mathematics Education

\section{Introduction}

Throughout the evolution of humanity, the discovery of mathematical knowledge has been of transcendental importance. The laws of mathematics reveal a higher harmony, despite the complexity of the world. Mathematical ideas are, in this view, the model of the perfection of the universe [1].

In the course of history, a lot of people were interested in the study of mathematics, creating and developing different symbols that contain the described ideas. Thus writing emerges and, in this way, the appearance of symbols that represent quantities, codes, messages or shapes also does (Figure 1). In this sense, humans learned to record the ordered behavior that they had discovered in the sky and in nature, which has allowed them, throughout history, to predict events that benefit or affect our survival and the equilibrium of the world [2].

The ancient inhabitants of Anáhuac (in the center of México), principally the Tlamatinime, were distinguished for being deep observers of astronomical 


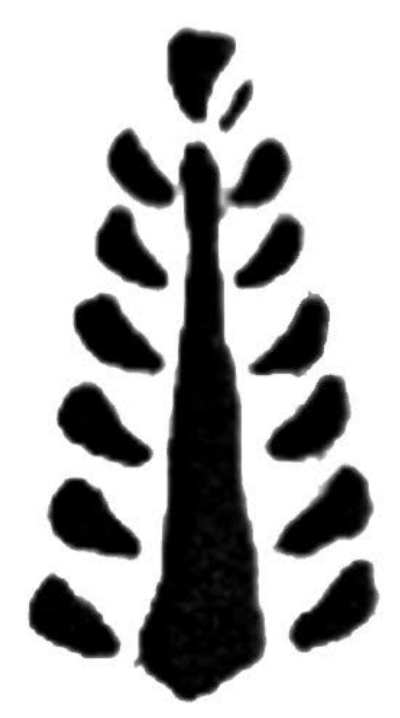

Figure 1. Tlamatinime, man of wisdom.

phenomena [3] [4].

They noticed that the stars always move preserving an order, that the sun "appeared" in a part of the skies and "hid" in another one, and that this apparent movement or translation was repeated after a certain period of time which they called semilhuitl (day). These observations gave beginning to the measuring of time (Figure 2).

They allowed enough precision for better calculations on when to work the ground, when to select the seeds, prepare the soil, sow and harvest the crop. This, in itself, was a way of harmonizing with the skies, the sun and the moon.

Because the Anáhuac people were aware that their own existence elapsed in the time, they measured both the duration and the repetition of the natural and cosmic phenomena to make up the calendars, which, although they were in some places still mysterious to us, were admirable systems of time measurement.

The Anáhuac people were also observers of their own being. They linked the tempo of their breathing, as the repetition and the tone of their heart's beats, with the measurement of time. Thus, their interest in the mathematics of rhythm was born.

Furthermore, the ability to calculate the time allowed them to observe the equilibrium between the light and the shadow through the seasons of the year, the equinoxes and solstices, the phases of the moon, the eclipses, the planetary conjunctions and other cosmic phenomena which involve the movement of the constellations of the sky.

The Anáhuac people developed rituals and festivals which were conceived to relate to and describe those perceived micro and macro rhythms, and to incorporate their own energy through dance (Figure 3). Dance was the Anáhuac people's most prominent manifestation of their understanding of the equilibrium of the world and their place in it.

These ceremonies were organised and developed in strict accordance with the 


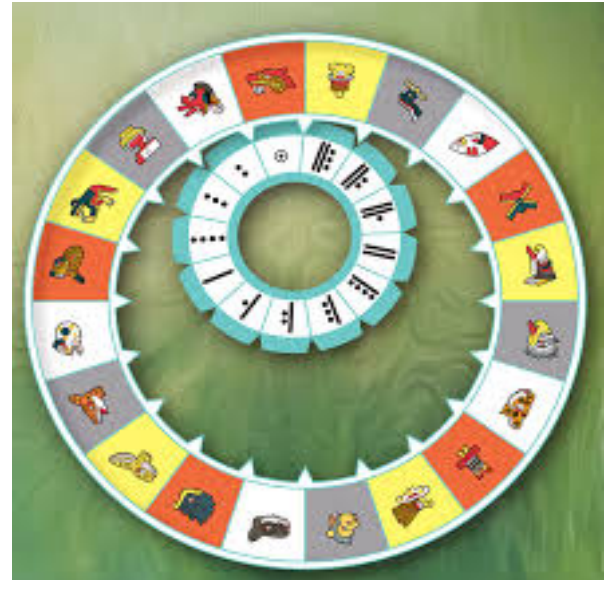

Figure 2. Numericalwheel.

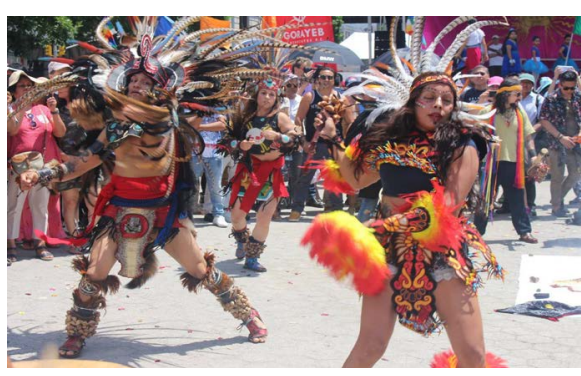

Figure 3. Contemporarydancers of Anáhuac.

calendars, which were incorporated into the activities linked to the growth of corn in agronomy and were directed towards maintaining the fertility of the fields, abundance in hunting and fishing, and to bring well-being to their communities (Figure 4).

\section{Numerical Meanings in Mesoamérica}

The numerals that arose in México and Central America (Figure 5) have been considered in the world as a great system of high rationality, emphasizing its quantitative value. But the qualitative value of the metaphorical message in the above context gives a different dimension to the mathematical interest of their creators. The meaning these symbols had for the Anáhuac people were linked to their enjoying a life of increasing plenitude, with the "supreme consciousness" of a harmonious existence.

They used a numerical system with base 20 , the vigesimal system, with a positional value and a symbol for zero. The system used by the Mayas was more advanced than that of other civilizations, because they solved situations of space in big numbers, which allowed them to recognize the magnitudes of the expressed numbers and to optimize the process of thinking. It is interesting to note that the most ancient evidence of the concept of zero and of its positional value comes from them too.

The Náhuatl civilization used the vigesimal system, probably learning from 


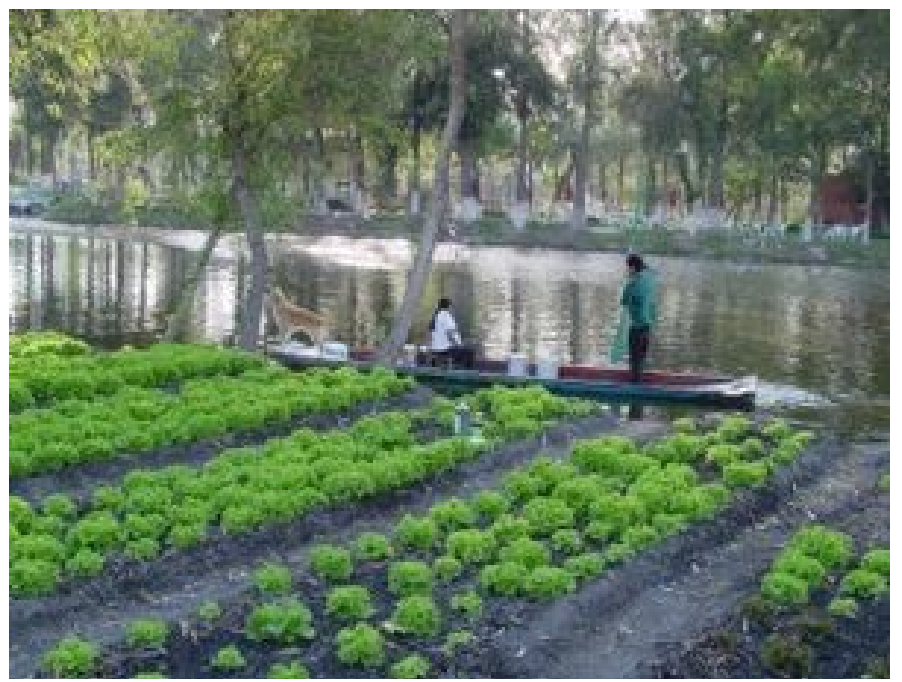

Figure 4. Chinampas, small land built on the lake for the farming system in Tenochtitlan.

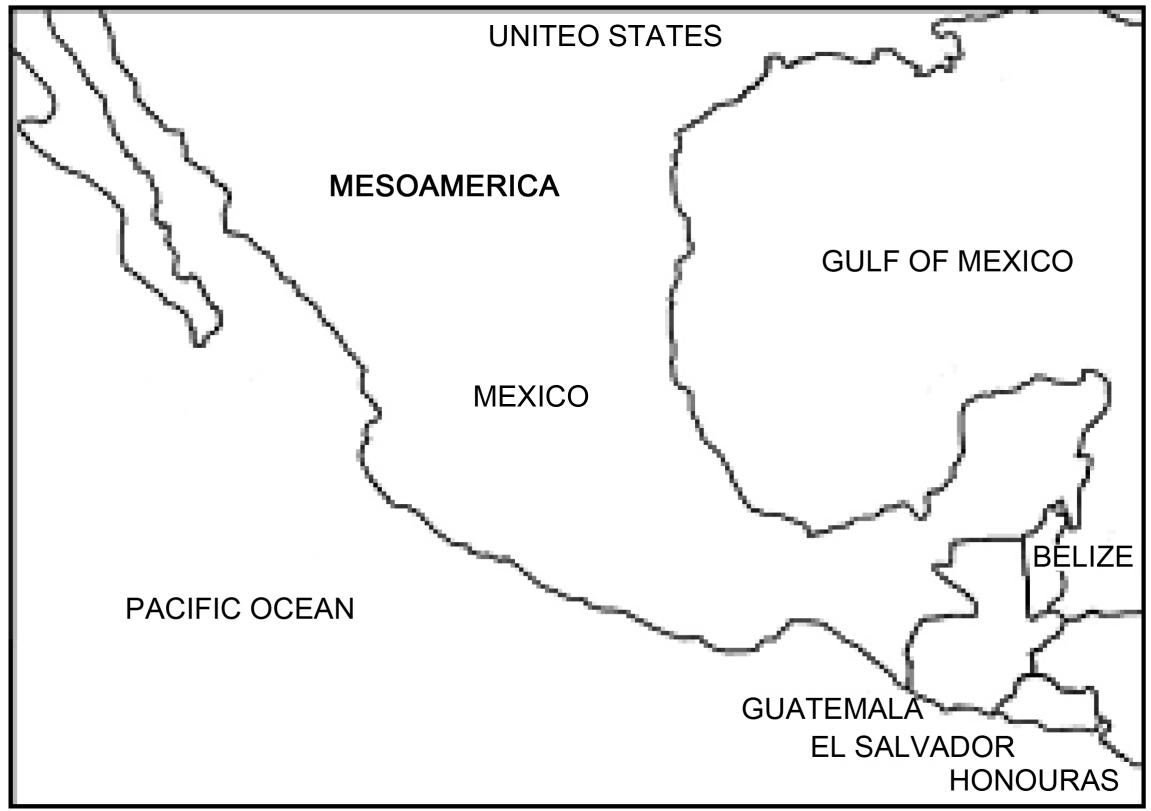

Figure 5. Map of the Mesoamerica area.

the Toltecas, who were influenced by the Maya. Everything coincides until the number 19, since for 20 they used signs that show the message of the way for transcending.The Náhuatl people had a process of learning from the beginning of the pilgrimage in 1111 until the foundation of Tenochtitlan in 1325. The Náhuatl numbering system corresponds to the observation, contemplation, visualization and communication of a figurative symbolic code of human activity.

\section{Symbolisms of Some Numbers}

The symbol of the zero can be seen in many artefacts of the ancient inhabitants 
of the American continents and is represented by an empty snail shell (Figure 6). When a snail dies it stays in its shell, which announces that a cycle of life has finished.

In the language of the Náhuatl, the number two is translated as ome. In the metaphorical interpretation of the "mathematical" Náhuatl language, ome means the essence of the equilibrium, a moment when part of energy converts into matter. This shows a principle of duality, manifested in people, in nature and in the cosmos. The human being, for example, requires the existence of the duality between man and woman, likewise we can think of duality between life and death and matter and energy. In the human body, the two is constantly manifested. We have the two hemispheres of the brain, two ears, two nostrils, two arms, two hands and two legs. We can say that a totality is formed by two corresponding and opposite strengths. With its basis in this principle, the Náhuatl civilization created the philosophical concept of Omeyotl (ome, two-yotl, creation): the eternal dual meaning of matter and energy; the origin of the universal whole.

Four is the number that represents the formation of the universe and the complete bodies that join in the whole. As the principle of the creation, the dual meaning is geometrically composed of two lines that (when they join) constitute the crossing that gives form to four regions. The four points that originate the foundational directions in the space are the points from the solstices, called cardinal ones. Theman/woman forms a square with his/her extremities (Figure 7).

For the Náhuatl, the number seven is linked to the representation of Chicomecoatl, which is a way of describing the flourishing of the corn seed into a cob. Metaphorically, Chicomecoatl can be seen as the origin of the seed of the human being, inside the cavity of the Mother Earth, formed in a flower of seven petals.

The ancient Mexican people perceived the vertical way of expansion in the human being as following the same logic as that of the growing Universe (Figure 8). In the human being, this way is seen by making the analogy with the thirteen joints of the body (Figure 9). The Náhuatl language describes this process as "aztliahmikiyan"- "the ascendant which is obtained with wisdom".

The number thirteen is seen as a symbol of expansion and simplicity of harmony. When we sum the first 13 natural numbers, we obtain 91 .

$$
1+2+3+4+5+6+7+8+9+10+11+12+13=91 .
$$
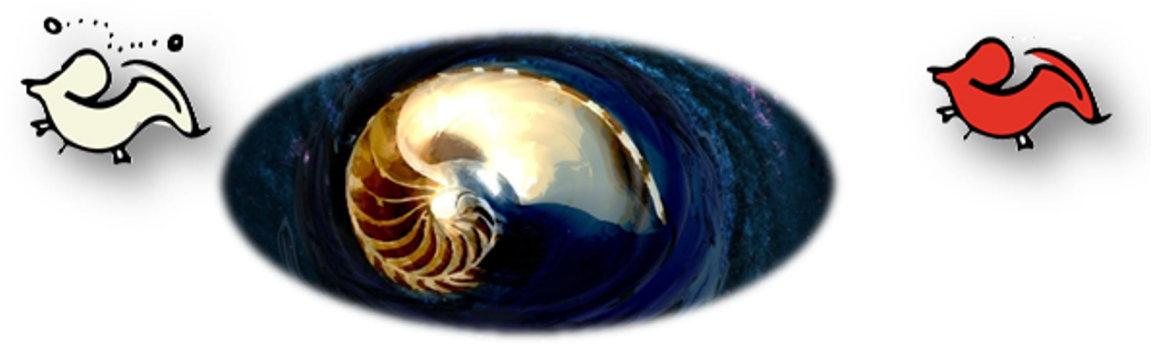

Figure 6. Image of a snail, corresponds to the Maya symbol of zero. 


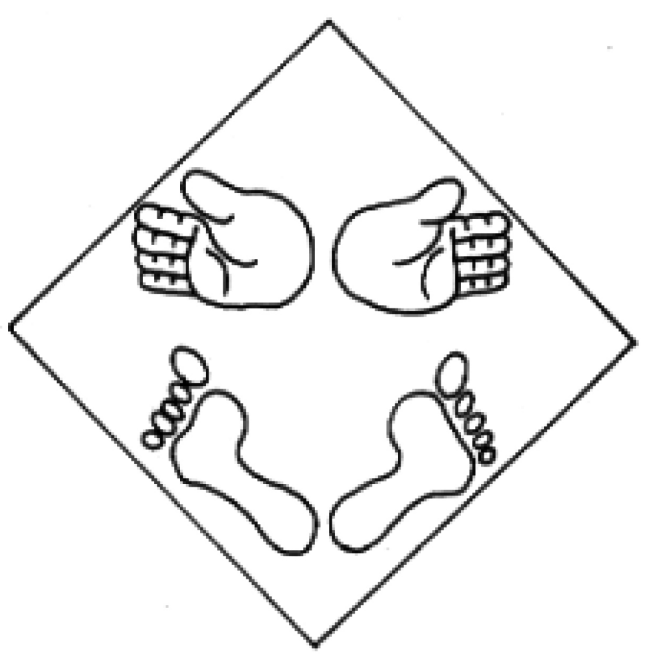

Figure 7. Image of hands and feet, representing the twenty units.

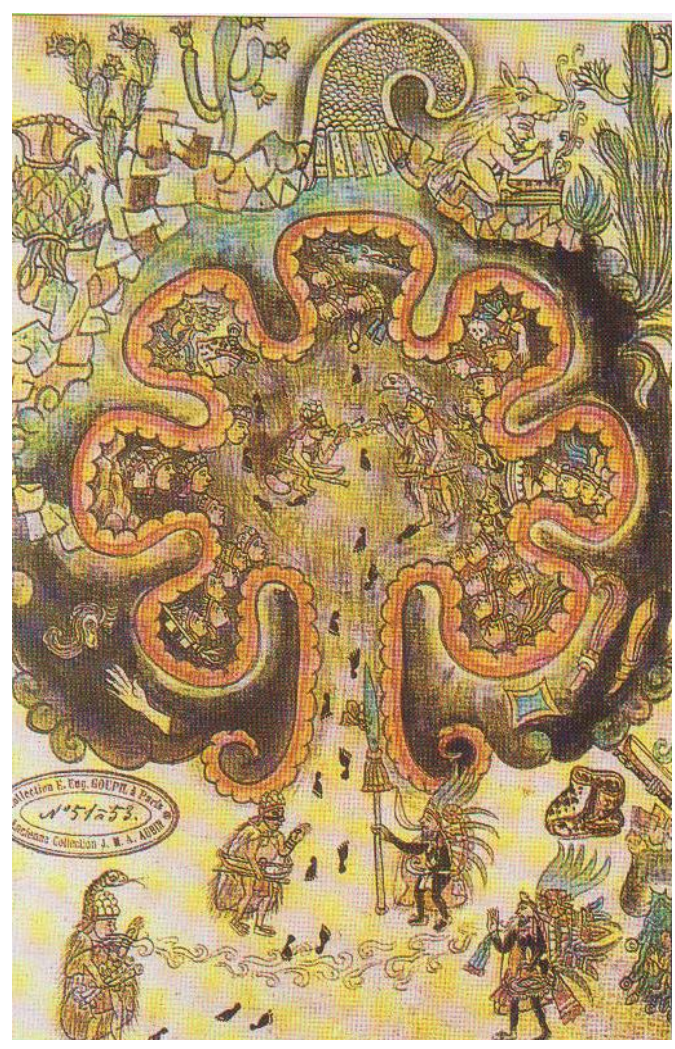

Figure 8. Representation of Chicomoztoc in the shape of a flower of seven petals.

Multiplying 91 with the numbers 2 and 3, we get the results of 182 and 273 the number of days needed to elapse for a single corn or a human being (respectively) to expand from a seed into a complete being. Combining 91 with 4, a year's cycle is fulfilled, where each 91 days anew season begins (spring, summer, autumn and winter). 


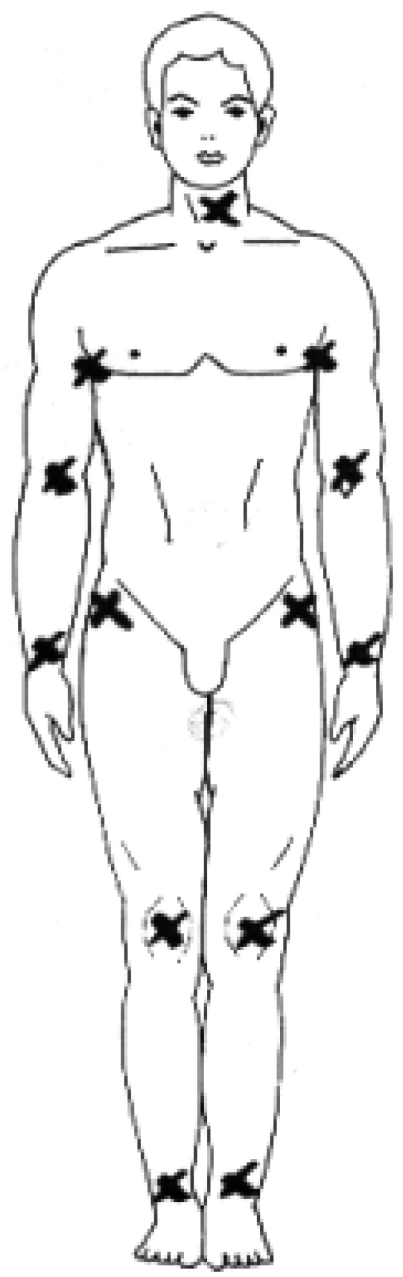

Figure 9. Representation of the thirteen major joints of the human body.

The fingers of the hands and feet are linked with the symbolism of the number twenty. In the Náhuatl language this is called cempohualli, which means the count of a complete body. Sketching horizontal dimensional lines of hands and feet, a human "square" of 20 elements is formed. Each human being is a vigesimal unit, since each of its four limbs has five fingers $(4 \times 5=20)$. The numeric word hunuinic has value of 20 , which means a person.

For the Náhuatl civilisation, the number of the whole human being is symbolized by a flag (pantli) (Figure 10). The calpulli is the formation of 20 families.

By combining, $20 \times 13=260$, which gives a result of a combination of the energy of the human and of the Mother Earth represented in the ritual count of the corn. Twenty also means "complete": when the families are joined, and in harmony.

In the ascending geometrical scale of a squarehe number $400(20 \times 20$ or the square of 20) arises. The Náhuatl language represents this number with a feather. 
In the same ascending scale, the number $8.000(400 \times 20)$ arises, where the incalculable count in the arch of heaven of the human mind rises to the count of the infinite sky. In the Náhuatl language this number is denoted by the word chiquihuitl, which also means "little hamper" (Figure 11).

In this way, the weaver of the hamper, or petate, keeps a symbolism with the supreme concept of the Universe, which can be observed, for example, in ceremonies of marriage in which the petate is used as a symbol of the rest of the divine duality in the cosmos. This number is shown graphically with a bag that can contain copal, seeds or tobacco. In the Náhuatl language, it is called xiquipilli (Figure 12).

\section{Náhuatlabacus: Nepohualtzitzin}

The Nepohualtzitzin sums up the mathematics of the ancient indigenous people, like others (Figure 13). The origin of the name of this calculating instrument is Náhuatl and its numerical structure corresponds to the Maya [5] [6].

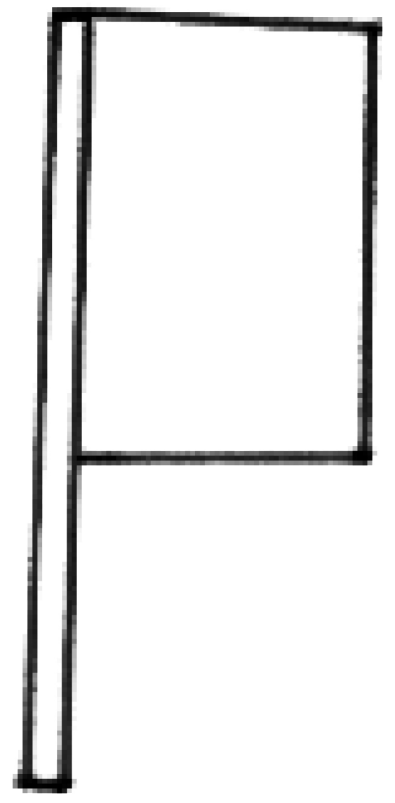

Figure 10. Vertical quadrangular flag symbol of 20 .

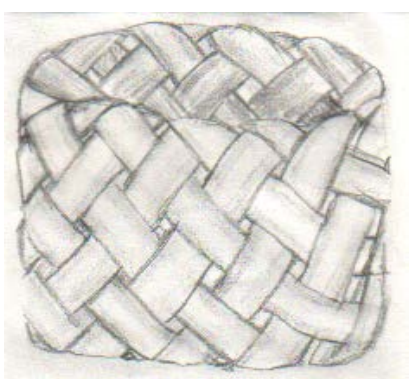

Figure 11. Chiquihuitl, small basket symbol of 8000 . 


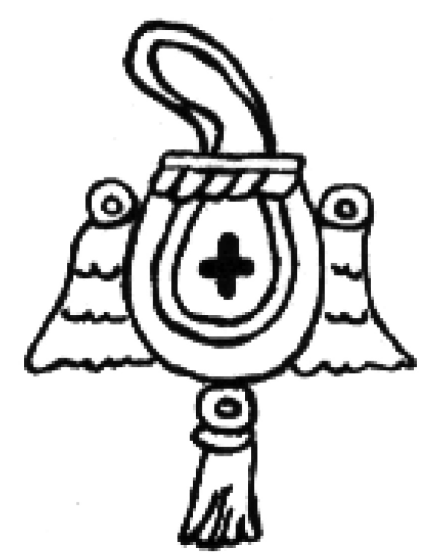

Figure 12. Bag, carrier of corn, cocoa and copal, also symbol of 8000 .

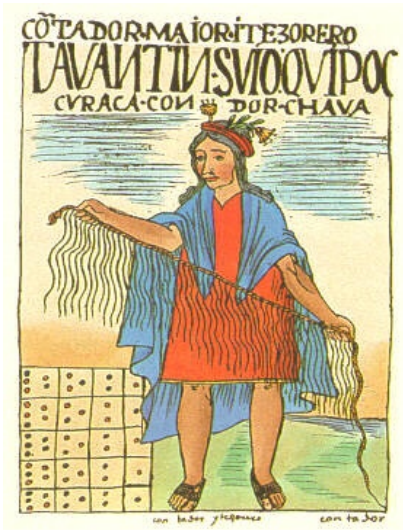

Figure 13. Quipu, an instrument of calculation of South America.

Both the Maya and Náhuatl systems use a dot to represent one and a stripe to represent five. In Náhuatl, Nepohualtzitzin means: Ne, suffix of person; Pohual, count; Tzitzin, the transcendental. It can be translated as "He who counts to 'goes beyond'", which is the core idea of its design [7].

The Nepohualtzitzin used seeds, which are represented in Figure 14. Each seed on this side (where there are four of them in each row) represents one unit. In the bottom row the exponent of the basis is 0 ; in the second it is 1 , and so on until the thirteenth exponent at the top, which is purple. Each seed on the other side of the picture (where there are three in each row) represents five units. A number is represented when you move the respective seeds to the center. The biggest number that can be represented is $20^{13}-1$ in 20th basis and $10^{13}-1$ in 10th basis. So, in Figure 14 the number represented is:

$$
10 \times 20^{2}+5 \times 20^{3}+7 \times 20^{5}+2 \times 20^{7}+3 \times 20^{10}=30,722,582,444,000 .
$$

It is possible to make the four basic operations with this instrument (addition, subtraction, multiplication and division) and it is also possible to use it to calculate square roots. Specific details are shown by [8] 


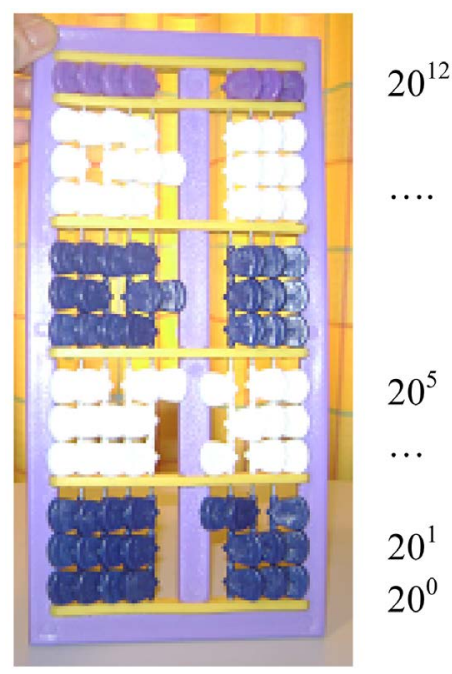

Figure 14. Nepohualtzitzin, an instrument of calculation, placed vertically corresponding to a base system 20 .

When, nowadays, we adapt the use of this instrument to the decimal system, we use it in a horizontal position, as you can see in Figure 15. The number represented in Figure 15 using the decimal version of the Nepohualtzitzin is:

$$
10 \times 10^{2}+5 \times 10^{3}+7 \times 10^{5}+2 \times 10^{7}+3 \times 10^{10}=30,020,706,000 .
$$

When we use the Nepohualtzitzin by its perimeter, we count 40 seeds, which symbolizes a complete count (20) of the man and a complete count (20) of the woman, resulting in $(20+20)$ : the Náhuatl count of the spiritual reflection. Combining the 20 with the dimensional scale of the 13 (the number of the joints), we obtain 260, which is the Náhuatl count of the destinies of the human being. The perimeter of the right hand side of the abacus is 28 , which represents a moon's cycle, and $28 \times 13=364$, which is the number of days in the Náhuat calendar year.

The substantial idea of this calculating instrument is: the person who has knowledge of how to count and calculate, thus, has access to the simplicity and the harmony of the universe, and the ability to transcend from this world to the origin of creation [9].

We have had several experiences with students and teachers in México and Argentina and other countries of Latin America, in which we used the Nepohualtzitzin as a didactical resource. This simple artefact has a strong potential for incorporating the indigenous peoples' metaphors and some historical reflections into the teaching of mathematics.

\section{Final Remarks}

In this article, we are attempting to invite mathematics teachers of all levels to reflect on the possibility of including historical aspects of mathematical knowledge into their classrooms. We believe that this approach puts the learner in an 


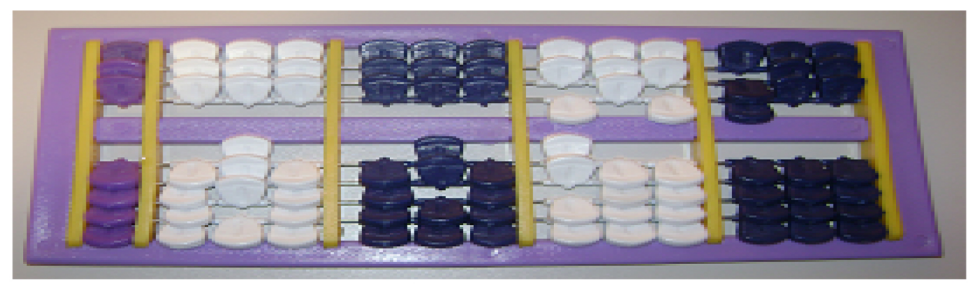

$10^{12} 10^{11} 10^{10} 10^{9} \quad 10^{8} \quad 10^{7} \quad 10^{6} \quad 10^{5} \quad 10^{4} 10^{3} \quad 10^{2} \quad 10^{1} \quad 10^{0}$

Figure 15. Nepohualtzitzin, placed horizontally corresponding to a base system 10 .

active position where they can investigate the relative merits of different mathematical systems. The Mesoamerican people, in their historical cultural tradition, believed that the principles of mathematics were the principle of order of all beings. It also allows to reconstruct the mathematical language of the different indigenous people in the educational process with an intercultural approach.

The use of Nepohualtzitzin in Mexican elementary schools has contributed to children being recognized as heirs of Náhuatl mathematics, finding different ways to solve problems, understanding mathematics at school and obtaining better results in the matter [10]. All this has favored the children's self-esteem. And it requires that teachers dare to use it in a systematic way and assume a less directive role, facilitating autonomous learning of their students.

Because the Nepohualtzitzin has two premises-that of a formal mathematical model of quantitative numerical representations and its complement, where the structure of philosophical thought is found through figurative representations, it is powerful for students to understand the message of order total, that is, the holistic aspect of the Mesoamerican worldview.

In this sense, we consider that teaching mathematics with its history can improve the attitude of the learners to mathematics [11]. This way of teaching mathematics is not about trying to "sell" a mounted project for the learner to "consume" without criticism. There are different stories and points of view in the history of mathematics. One of them is that of the ancient Latin American people.

\section{References}

[1] Lara, E. (2004) Mi trascender a través de la cuenta y el juego. Metáfora espiritual matemática. El Angelito, México.

[2] León, M. (1979) La filosofía náhuatl. UNAM, México.

[3] Caso, A. (1956) El calendario mixteco. Historia Mexicana, 5, 481-497.

[4] Caso, A. (1967) Los calendarios prehispánicos. UNAM, México.

[5] Esparza, D. (1976) Cómputo azteca. Diana, México.

[6] Esparza, D. (1978) Nepohualtzitzin, computador prehispánicoen vigencia. Diana, México.

[7] Carpanta, L. (1986) Idioma azteca. Lecciones y ejercicios. Popular, México.

[8] Lara, E. and Flores, A. (2009) Manual didáctico del Nepohualtzitzin para el 
desarrollo de las competencias matemáticas. SEP, México.

[9] Lara, E. and Sgreccia, N. (2008) Nepohualtzitzin, muchomás que un instrumento de cálculo. VII History and Pedagogy of Mathematics Meeting, México.

[10] Lara, E. and Lara, J. (2014) Nepohualtzitzin: un modelo matemático náhuatl. Revista Digital Universitaria, 15, 2-14.

[11] Lara, E. and Sgreccia, N. (2010) Nepohualtzitzin: Un modelo matemático de cualidad. RevistaLatinoamericana de Etnomatemática, 3, 24-54. 